\title{
MSH2 wt Allele
}

National Cancer Institute

\section{Source}

National Cancer Institute. MSH2 wt Allele. NCI Thesaurus. Code C50993.

Human MSH2 wild-type allele is located within 2p22-p21 and is approximately $80 \mathrm{~kb}$ in length. This allele, which encodes DNA mismatch repair protein Msh2, is involved in the repair of post-replication insertion-deletion looped DNA mismatches. 